Article

\title{
Impacts of the Fossil Fuel Divestment Movement: Effects on Finance, Policy and Public Discourse
}

\author{
Noam Bergman \\ SPRU-Science Policy Research Unit, University of Sussex, Brighton BN1 9SL, UK; n.bergman@sussex.ac.uk; \\ Tel.: +44-1273-873875
}

Received: 29 May 2018; Accepted: 17 July 2018; Published: 19 July 2018

check for updates

\begin{abstract}
The fossil fuel divestment movement campaigns for removing investments from fossil fuel companies as a strategy to combat climate change. It is a bottom-up movement, largely based in university student groups, although it has rapidly spread to other institutions. Divestment has been criticised for its naiveté and hard-line stance and dismissed as having little impact on fossil fuel finance. I analyse the impact of divestment through reviewing academic and grey literature, complemented by interviews with activists and financial actors, using a theoretical framework that draws on social movement theory. While the direct impacts of divestment are small, the indirect impacts, in terms of public discourse shift, are significant. Divestment has put questions of finance and climate change on the agenda and played a part in changing discourse around the legitimacy, reputation and viability of the fossil fuel industry. This cultural impact contributed to changes in the finance industry through new demands by shareholders and investors and to changes in political discourse, such as rethinking the notion of 'fiduciary duty.' Finally, divestment had significant impact on its participants in terms of empowerment and played a part in the revitalisation of the environmental movement in the UK and elsewhere.
\end{abstract}

Keywords: divestment; fossil fuels; impact; social movements; environmental movements; stranded assets; activism; climate action

\section{Introduction}

In recent years, there has been recognition in policy circles and beyond that to avoid dangerous climate change, most fossil fuel reserves will need to be 'left in the ground' (e.g., [1]). This was popularised by the Unburnable Carbon report [2], which suggests that burning currently known fossil fuel reserves would emit nearly 5 times the $\mathrm{CO}_{2}$ that is in the carbon budget through 2050, if we are to limit global warming to $2{ }^{\circ} \mathrm{C}$. Similarly, McGlade and Ekins [3] suggest global reserves are 3 times higher than the budget which would give us a $50 \%$ chance of staying below $2{ }^{\circ} \mathrm{C}$. However, the global economy is locked-in to fossil fuel supply through infrastructure and investment (e.g., [4]), and, moreover, fossil fuels are "are integrated in modern economies in complex ways" [5]. Moreover, while historically the developed world is responsible for the large majority of emissions, fossil fuel extraction could now be key to economic development of lower income countries [4] and projected emissions increases are greatest for developing countries, making any shift away from fossil fuels an economic and political challenge involving global inequalities.

The fossil fuel divestment movement (henceforth: Divestment) calls for a financial shift of removing investments from fossil fuels as a strategy to reduce greenhouse gas emissions. It is a global social movement that emerged in the early 2010s and has grown and spread rapidly, gaining much public attention in a short time [6,7]. At the heart of Divestment is 350.org, an international network of local groups and activists, who describe themselves as a movement more than an organisation and use "distributed, grassroots organising to run adaptive, locally-driven campaigns" [8]. 
Divestment has been criticised for having no significant impact on fossil fuel funding and for its political and financial naiveté (e.g., [9]). While it is true that funds divested to date have been far too small to financially challenge the global fossil fuel industry and its financiers, the divestment movement has been described as a 'moral entrepreneur', due to its distinctive approach based on morality [6]. Divestment could be shaping up to be a disruptive innovation, playing an important part of a strategy to rapidly de-carbonise the global economy [7].

This paper aims to unpack the impacts of the divestment movement and consider its significance in the transition to a low carbon economy, contributing to the understanding of civil society participation in global governance. I start from the view that the movement's indirect impacts are far more important than its direct (financial) impacts (e.g., [10]). Using literature review and analysis, complemented by UK-based interviews, the impacts of Divestment on public discourse, climate policy and climate finance are explored using concepts from social movement theory. The rest of the introduction offers a brief introduction to the divestment movement; Section 2 describes the methodology and theoretical framework used; Sections 3 and 4 describe the findings for Divestment's direct and indirect impacts, respectively; and Section 5 offers a discussion and conclusions.

\subsection{A Brief History of Divestment}

The divestment movement began in the summer of 2011, when student activists launched campaigns in six universities in the US to divest their endowments from coal [11]. More than 50 US universities had divestment movements by spring 2012, which broadened to a call to divest from all fossil fuels and invest in clean energy.

The movement grew considerably in 2012 due largely to the climate advocacy group 350.org, founded in 2008, who describe themselves as "building a global grassroots climate movement that can hold our leaders accountable to the realities of science and the principles of justice" [8]. 350.org joined forces with the student activists and launched its divestment campaign in 2012, with co-founder Bill McKibben relying on the Unburnable Carbon report [2] in his popular article, Global Warming's Terrifying New Math [12]. The divestment campaign argues for collective political action, highlighting that individual action on climate change is not enough $[7,12,13]$.

In 2012, 350.org and its affiliates started the Go Fossil Free campaign, whose goal is to get "institutional leaders to immediately freeze any new investment in fossil fuel companies and divest from direct ownership and any commingled funds that include fossil fuel public equities and corporate bonds within 5 years" [14]. In the past few years, the movement has grown considerably and there are currently fossil fuel divestment campaigns in hundreds of universities worldwide, including dozens in the UK, as well as local authorities and other institutions. Many of the groups involved are student organisations [6], although religious organisations, local and regional governments and other public bodies have also divested, or have been targeted by divestment campaigners. Finally, it is worth noting that the divestment movement is so far overwhelmingly concentrated in the developed world [6].

\subsection{Politics of Divestment}

Divestment takes a hard-line, uncompromising position on the fossil fuel industry and parts of the finance industry, attempting for example, to generate fear and anger over the results of the coal industry's activities $[6,15]$ and comparing itself to the anti-apartheid divestment campaigns of the 1980s. This is not coincidental: McKibben [12] suggests that moral outrage might spark transformative change and noting that social movements require enemies, he proceeds to paint the fossil fuel industry as the adversary/villain of climate change [7,12].

The call to simply pull investments out of fossil fuel funds has been criticised as simplistic and naive $[9,16]$. However, the literature suggests Divestment activists are well aware that the direct effect of some investors withdrawing their investments will do little harm to fossil fuel companies $[6,10,11,17]$. Rather, Divestment can be seen as a tool to confront corporate power [11] and change the narrative around climate change [17]. 
The complementary side to divesting money from fossil fuels is reinvestment in climate mitigation measures such as renewable energy, energy efficiency, low carbon infrastructure and demand reduction. Reinvestment has been less prominent than divestment in the grassroots movement, although it has been part of the campaign from the start, for example, investment in clean energy was part of the initial 'divestment mix' when the movement began [11]. In 2013, 350.org published a reinvestment guide for university campaigners [18] and Power Shift (a USA-based youth and university student movement) still calls for universities to reinvest $5 \%$ of their endowment in "climate solutions" as part of their divestment campaign [19], but these have not been the headlines of the campaign in the past few years.

The idea of divestment has broadened out beyond the original student groups and socially minded institutions. There are now some who link the idea explicitly to economic arguments, pointing out that fossil fuel companies and their assets are currently overvalued, as much of their reserves will not be extracted if climate targets are to be met. The economic risk is that fossil fuel reserve and infrastructure values will fall drastically at some point due to being unusable (becoming 'stranded assets'); this potential 'price correction' makes many investments unsafe and could severely affect the global economy as the 'carbon bubble' bursts [2,20]. More recently, another set of economic arguments has appeared by directly comparing investment portfolios with and without fossil fuels and assessing whether performance will be affected (e.g., $[11,21])$. Those focusing on economic arguments often present a less radical branding that is more suitable for mainstream investors, by highlighting the Paris Agreement (the international agreement dealing with climate change risk and greenhouse gas emissions mitigation, with the long-term goal of keeping global warming to well below $2{ }^{\circ} \mathrm{C}$ ) and economic investment futures (e.g., [22]).

In the UK, Divestment is coordinated primarily by two organisations that cooperate with each other: People \& Planet coordinate the student part of the movement and work closely with the National Union of Students; and 350.org, who work with local councils and pension funds. There are other smaller Divestment organisations too.

\section{Methods and Framework}

\subsection{Literature and Interviews}

This work was based on a literature review of the divestment movement, including academic papers, grey literature and websites of organisations involved in Divestment. In order to get a feel of different perspectives and experiences around the movement, I considered work that included participant observation and interviews with Divestment activists $[13,17,23]$. This was complemented by a small number of interviews conducted with present and former activists, as well as several actors in the finance sector who have an interest in environmental, social and governance (ESG) issues, including climate change related finance.

This twelve interviews are listed in Table 1. I interviewed eight people specifically about divestment (interviewees A1-A8), most of whom are or were involved in the divestment movement. I conducted another four interviews with actors from the finance sector (B1-B4), covering various topics on finance and sustainability (used in another part of the same research project), which included questions specifically about their perspective on the divestment movement.

All of the interviews were recorded and professionally transcribed. Discourse analysis was used to analyse the transcripts. I used manual coding to highlight recurring themes, which were loosely defined and evolved as the research progressed and the theoretical framework was built. The themes coded for were: backgrounds and justifications for divestment; actions, tactics and media; organisation; direct impacts; indirect impacts; reaction and resistance to divestment; attitudes to students and campaigns \& critiques of divestment; mobilisation, mainstreaming \& discourse change; and reinvestment. I concluded from the review and interviews that the effects of Divestment could be analysed as impacts of a social movement. The framework developed is detailed in Section 2.2. 
Table 1. List of interviewees.

\begin{tabular}{cc}
\hline Interviewee & Background or Profession \\
\hline A1 & Student campaigner \\
A2 & Former divestment student activist \\
A3 & Project and research officer at a charitable trust \\
A & Former divestment student activist \\
A5 & Chair of a research and advocacy group \\
A6 & University academic involved in divestment \\
A7 & Campaigner at People \& Planet \\
A8 & University finance director \\
B1 & Investment bank research analyst \\
B2 & Independent investment consultant \\
B3 & Senior economist in a fossil fuel corporation \\
B4 & Chief investment officer of a large pension scheme \\
\hline
\end{tabular}

\subsection{Developing a Framework}

\subsubsection{Divestment as a Social Movement}

Reviewing the social movement literature, Snow et al. [24] conceptualise social movements as a form of collective action for the purpose of challenging (or defending) institutional or cultural authority. Social movements require some degree of organisation but in contrast to interest groups they are typically outside of institutional channels. Finally, they require some degree of temporal continuity to pursue their goals. The student-based divestment campaign comfortably falls within this conceptualisation, with its goal-oriented challenge of financial institutions and culture. From a temporal perspective, Divestment could be seen as its own social movement active since 2011/2012, or alternatively as the latest incarnation of the climate movement.

\subsubsection{Impacts of Social Movements}

I draw on social movement theory to consider Divestment's impacts, acknowledging the difficulty in distinguishing the impacts of environmental movements from impacts of other actors and events [25]. My framework combines a social movement framework on different categories of impact [26] with the concept of direct and indirect impacts, which has already been used in the Divestment context [10]. In addition, I acknowledge the importance of personal experience of participants. I therefore consider three dimensions of impacts: categories of impact; direct and indirect impacts; and impacts of action versus impacts on participants.

Given the issues of direct financial impact on the fossil fuel industry and its investors on the one hand, and the potentially greater impact through discourse change or policy shift on the other, I found it useful to build on Staggenborg's framework defining three categories of social movement impacts [26]: Political impact can include influencing policy and power structures; getting demands on the political agenda; influencing public opinion; and gaining recognition of a group as legitimate representatives of an issue [26,27]. Mobilisation impact refers to organisational success and the ability to carry out collective action and affect the context for future mobilisations [26,28]. Cultural impacts can include creation of new identities and developing a collective consciousness among participants; and more widely, changes in public discourse, social norms, behaviours and institutional practices [26,29]. Finally, in the case of divestment, financial impacts are central: changes to actual financial investments, financial certainty and viability of investments in fossil fuel related funds, creation of 'fossil free' funds and shifting norms in the finance sector. Financial impacts are therefore considered as a fourth category, peculiar to this study, although there are clear overlaps, for example, indirect impacts affecting the world of finance could be seen as cultural or as financial.

The second dimension considered is the distinction between direct or material impacts, for example, impact of money already divested on the fossil fuel and finance industries; and indirect or contextual 
impacts, which have long-term significance, through shaping socio-economic and institutional context and norms, even if their immediate effect is small $[10,28]$. Direct impacts are not only financial. They could include political impacts, for example, universities changing their investment policies following divestment campaigns and impacts on participants, for example, politicisation of students. I suggest that direct impacts are generally easier to attribute to social movements than broader and longer-term indirect impacts, while also acknowledging that distinguishing direct and indirect impacts is to some extent interpretive.

Finally, I consider impacts on participants, which can affect the movement internally and impact its strategies and longevity, in addition to impacts of the actual Divestment campaign. I have not developed this dimension as much as the other two in this paper but still consider its importance in shaping the dynamics of a social movement.

The next sections detail the findings through the lenses of these different dimensions of impact, with 3 focusing on direct impacts and 4 on indirect impacts.

\section{Direct Impacts of the Divestment Movement}

My findings suggest that the direct impacts of divestment can be clearly divided between the effects on participants in the movement, which can be categorised as primarily cultural and mobilisation impacts; and the effects of the campaigns on their targets, which include political and financial effects on the universities targeted and the impacts of withdrawing funds from fossil fuel companies (or commitments to doing so).

\subsection{Effects on Participants-Cultural and Mobilisation Impacts}

Most of the activist interviewees mentioned the empowering effect Divestment had on participants. Interviewees suggested Divestment had a clear message of something people could do to make a difference, giving students who were not focused on environmental work or studies a way to engage with climate change, beyond preaching to people to change their individual behaviour. A former student activist (A2) explained her motivations:

The whole point is that a lot of people's ability—or perception of their ability — to do anything about climate change is completely constrained by the perception that the problem is too big. It's too abstract, it's too global, it's too long term.... After talking about climate change for years and years and years, it's nice to have something that you feel that you can actually [do] ... A goal that you can attain in a reasonable timeframe.

Similar sentiments of an opportunity to get involved in politics through collective action were expressed by students involved in the 'Fossil Free Sussex' campaign at the University of Sussex [23].

This suggests that the grassroots, targeted campaigns gave people the feeling of agency. This effect on participants can be seen as a cultural impact, in forging new identities and awareness.

Beyond individual effects, Divestment played an important mobilisation role for the global environmental movement. In the early 2010s NGOs had trouble motivating the public to take action on climate change, while young activists lacked a platform with which to engage climate change issues [11]. The divestment movement acted as a 'rallying call' [30], contributing to the reappearance of student activism in the UK [31]. On the other hand, the problematic side of student activism was acknowledged: the need to 'refresh' people and energy, as students move on quickly, with Divestment having a high level of 'burnout' (A5).

A few interviewees suggested Divestment had the additional (cultural and mobilisation) impact of engaging students in broader environmental issues, increasing the size of the environmental movement. Participants were politicised and one campaigner (A7) stated:

I've seen people, after a year or a year and a half of organising for divestment, leave with a much deeper, more coherent radical politics ... than when they arrived and go on to continue organising with that in mind. 
Divestment marked a shift from individualised efforts to collective political action on climate change [13]. This matches other findings about the environmental movement contributing to the vitality of democracy, not least through attracting young people for whom mainstream politics hold little interest [25]. The draw of environmental movements is the practical, demonstrable impacts they promise, at least at the local level; this could apply to the idea of achievable (university) divestment.

From a mobilisation point of view, Divestment offered organisational learning. University campaigns drew on various tactics, including negotiation and collaboration with university authorities but also tactics of reputational damage or direct action against them. UK wide, the student movement is coordinated by People \& Planet (A7), allowing new campaigns to learn quickly from previous ones.

\subsection{Direct Financial and Political Impacts}

From a financial perspective, divestment commitments so far are small on the global scale and sometimes only partial but they do include some influential institutions [6]. However, there are signs that early adopters have begun a substantial asset movement worth $\$ 2.6$ trillion [32]. While oil and gas might not feel the direct impact of divestment, coal might already be suffering from divestment and perceived financial risk [10] as insurance companies have pulled out equities and bonds worth $\$ 20$ billion from coal investments and a growing number are refusing to underwrite new coal projects, making them uninsurable [33].

This global divestment is the sum of many actions of divesting funds, big and small, many of which can be linked to the bottom-up movement. For example, Kemp [34] finds that the strongest force behind divestment in Australia is "simple public pressure from concerned citizens, investors and students." Furthermore, it is not the powerful actors who are taking action [34]: some local government is divesting, while the federal government are still making fossil-fuel industry friendly policies; smaller banks have responded to climate concerns, while the largest ones fund the fossil fuel industry; and Australian universities which have divested have all had 'fossil free' campaigns in them, that is, this has been bottom-up action and not proactive action by university administration.

Interviewees suggested that nearly half of UK universities had pledged divestment, usually following divestment campaigns on their campuses. While some pledges had an unrealistic timeline, or committed to divest from some but not all fossil fuels (e.g., coal and tar sands), these were still accountable, public pledges. Some universities, such as University of Sussex, did not, strictly speaking, commit to divest; however, they discussed the broader issues of SRI (socially responsible investment) and chose to move investments to an ethical fund which does not invest in fossil fuels, among other things. The divestment campaign in this case caused a broader rethinking of investment policies, an example of direct, local political impact.

In the age of neoliberal education, where students are treated more and more as consumers, students realised that they were 'constituents' who could make demands. Divestment used this to its advantage, for example, Fossil Free Sussex focused on re-empowering the student voice on campus [23]. Some interviewees saw this approach as one of the reasons for successful university campaigns.

The direct impacts of Divestment are summarised in the top half of Figure 1, with effects on participants seen as cultural and mobilisation impacts and effects of divestment campaigns as political and financial impacts. 


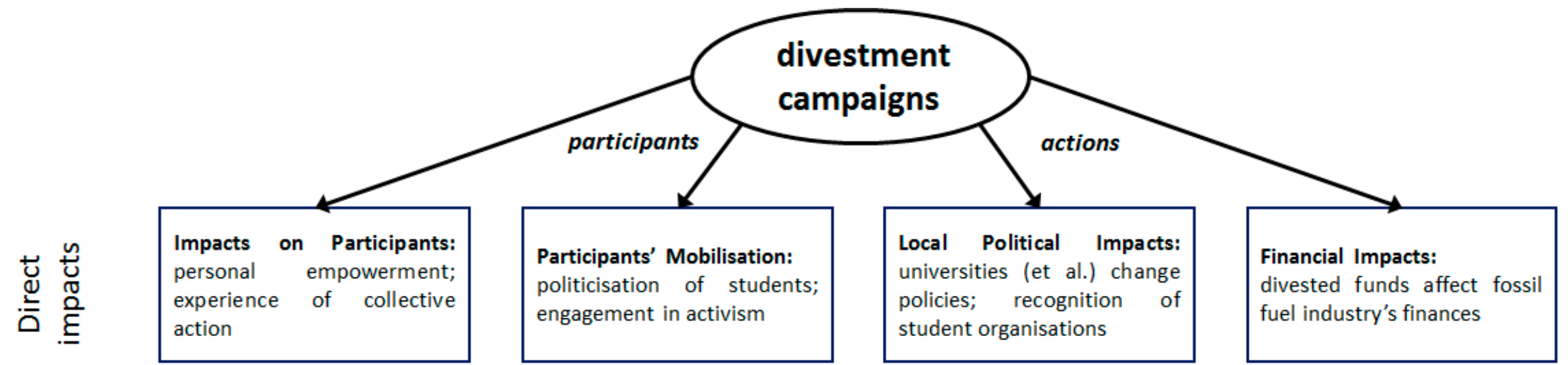

\section{Impacts on Society:}

expanding climate change debate; reframing of ethical investment; powerful actors pressured to act and declare

Societal Mobilisation:
shareholder $\begin{aligned} & \text { activism; } \\ & \text { investors, other actors, } \\ & \text { asking questions; resurgence } \\ & \text { of climate movement }\end{aligned}$

\section{Broader Political Impacts:}

political agenda and

discourse shift; legitimacy of

industry reduced; legal and

regulatory changes

\section{Financial Impacts: \\ fossil free funds crated; \\ financial actors debate, take \\ action or resist; uncertainty \\ around future of fossil fuels}

\section{Cultural}

\section{Mobilisation}

\section{Political}

\section{Financial}

Figure 1. Divestment impacts framework. I attempt to tease out categories of impact: cultural, mobilisation, political and financial (left to right). I further distinguish direct impacts from divestment action (top), which can be attributed more clearly to the Divestment movement, from indirect impacts, which are more complex and rely on various events and processes but in which Divestment has played a part (bottom). Finally, impacts on participants are clearly distinguishable in the direct impacts but less prominent in the indirect impacts and harder to separate from impacts of divestment actions. 


\section{Indirect Impacts of the Divestment Movement}

Previous work [10] suggests that the direct effect of the divestment campaign (on equity, debt, etc.) pales in comparison to its indirect effect through stigmatisation of the fossil fuel industry and increasing uncertainty around its longer-term financial viability. Here I consider a variety of indirect impacts on public discourse, policy, the fossil fuel industry and the finance sector. It is difficult to assess how much of a role Divestment played in indirect impact, as it is part of a larger picture of changing discourse, policy, finance and attitudes. In addition, the distinctions between impact categories, such as cultural and political, is to some extent a matter of interpretation. This section therefore uses a few different angles to explore indirect impacts, starting with an in-depth view of changing discourse and how that affected the world of finance. I then shift to other angles, including the impact on legitimacy and reputation of the fossil fuel industry; the radical flank effect; the political shift around fiduciary duty; and finally, the question of reinvestment of divested funds.

\subsection{Changing the Discourse}

Interviewees involved in activism believed great changes were happening. For example, a former student activist (A4) explained, "[Divestment] generate[d] conversation where the conversation was not being had before." Similarly, a student organisation campaigner (A1) suggested that "people are more motivated and less scared about understanding finance; they want to know where their money is." A university academic (A6) noted that even parliamentarians are asking about how their own funds are being invested. This section analyses this discourse shift and its impact.

\subsubsection{Public Discourse Shift}

One of the most important impacts of Divestment has been changing public discourse. Issues of investments in fossil fuels have become more prominent on both political and financial agendas and Divestment may have already had significant impact on public discourse around climate mitigation $[6,30]$. Signs of this shift can be seen in effects on where and how divestment is discussed and more broadly in its mainstreaming.

The divestment critique has been adopted by powerful financial actors, although they use more politically palatable concepts and business language (e.g., stranded assets, unburnable carbon) and present it as a financial risk challenge [35]. A shift in language can accelerate public discourse change and in this case, it "allowed the divestment message to broaden its category of influence and gain more attention, especially among dominant business actors" ([35], p. 26). In this Divestment has departed from other discourses around climate change (A2, former student activist). Moreover, an academic (A6) noted that divesting funds used narrow financial and legal arguments, preferring not to admit their actions had to do with climate change, let alone campaigners-not wanting to encourage activists by giving them credit. While this language does not support the systemic change favoured by Divestment [17], it still shows that the topic cannot be ignored.

There are also various signs of divestment becoming more mainstream. An interviewee from a charitable trust (A3) observed mainstreaming reflected in the type of people embracing divestment as a legitimate strategy of investment. One campaigner (A7) explained how there is now little pushback from (UK) universities, with some signing up to divest on request, with no campaign on campus. A few interviewees mentioned fairly positive media coverage and overall it seems the movement succeeded in creating "a high profile and media friendly debate" [30]. However, it is now harder for campaigners to get media coverage when a university or other institution commits to divest (A7), another sign of normalisation.

\subsubsection{Investors Raise Questions}

The experience of some interviewees suggests that investors want to better understand issues of divestment, stranded assets and an economic transition away from fossil fuels. Corporate pension schemes are looking to understand these investment issues more (A3) and various investors are 
going to talks by the likes of Carbon Tracker (B1, research analyst). There is growing interest in the approaching 'investment horizon' of fossil fuels (B4), with shareholders demanding disclosure of fossil fuel project 'exposure' (A6, academic). An economist in a fossil fuel corporation (B3) noted a spectrum of growing interest from investors, from those asking questions about stranded assets, divestment and how the company was addressing climate change, to those who pull their money out; he believes the change is linked to the social movement.

Interviewees from the finance sector mostly agreed Divestment had raised the profile of fossil fuel investment issues in finance circles, with one from a research and advocacy group (A5) suggesting the divestment campaign has "pushed climate change up the agenda of pension funds and investment managers hugely... in ways that none of us have been able to do before" and an investment officer (B4) suggesting some institutions were divesting as a result. The effect was perhaps best summed up by a charitable trust officer (A3):

We regularly host events where we bring together fund managers, asset owners and consultants to discuss the issues. In many cases, they would probably not be there were it not for the efforts of students and others to raise this up the agenda.

While opinions on divestment as a strategy varied, only one interviewee, an independent consultant (B2), did not believe the divestment movement had played any role in raising these issues, as "it's a group of people talking to themselves. And their access to the world of finance, is very, very limited." Nonetheless, it is hard to deny that the investment community's thinking is changing, as evidenced by the debate at the World Economic Forum in Davos about the risk to the global economy from overvalued fossil fuel stocks [11].

The increased scrutiny by investors and shareholders is forcing companies to respond to questions about their strategy for managing assets when reports suggest fossil fuels have to stay in the ground (A6). Meanwhile, the breadth of fund managers who work for universities, faith groups and foundations has helped take divestment discussions into private sector boardrooms, creating a ripple effect (A3). The next section focuses on responses in the finance sector.

\subsubsection{Finance Responds}

Divestment seems to have imparted a need for action on finance and climate change in the finance world, where a discussion has developed around the pros and cons of divestment versus alternatives; this discussion is itself evidence of impact. For example, a charitable trust officer (A3) explained that decision makers who do not divest are forced to say what they are doing and how it compares. Certainly, some consider engagement to be a better strategy, as an economist in a fossil fuel company (B3) explained: "It is people who are actively engaged with staying invested but trying to have an influence rather than people who just want all the money out." A good overview of this discussion is offered by an experienced advocate for responsible investment in a piece exploring "pro- and anti-divestment camps" for common ground [36]. He goes on to criticise those in the finance world who oppose Divestment but take no other action, as they:

have shown little willingness to engage with policy decision-makers with the publicity and assertiveness required. This calls into question whether these divestment critics are really looking for the best system change strategy or whether they are simply looking for reasons to justify their inaction. [30]

Some changes are already visible. A university finance manager (A8) suggested that markets and investment managers are "already pricing in the fact that they know that fossil fuels will make money for a [limited] number of years on the horizon" and as a result some funds are 'underweight' in fossil fuels. Some interviewees noted the increase over the past few years in available funds that do not invest in fossil fuels, suggesting that there did not used to be any (A2, A8). Alongside newly launched funds, there are those divesting from some or all fossil fuels, including high profile divestments such as the Rockefellers [37]. These changes have made divestment more viable for universities and other institutions. 
Finally, Divestment has touched the fossil fuel industry, with some companies publishing documents countering arguments of stranded assets [6]. Exxon, for example, felt the need to justify why its assets are not at risk of being stranded, claiming that all its reserves will be needed-and was accused of naivety [38]. One interviewee (A6) suggested that Exxon defending its viability and using the language of stranded assets was evidence that the industry has to "play on our grounds." The fact that "shareholders asked for and these companies felt the need to fashion, detailed defences of their positions suggests that the divestment movement is increasingly having an impact" ([6], p. 139).

This trail linking changing discourse from grassroots activism to changing behaviours in the finance and fossil fuel sectors suggests that Divestment has played an important role in a profound change, with cultural, political and financial impacts. In other words, "Grassroots support through the divestment movement is rapidly spreading worldwide, creating stakeholder-driven support for action on climate change" ([39], p. 486). The cultural impact of discourse change has in turn catalysed other impacts, including mobilisation among shareholders and investors as awareness was raised, political impacts as public opinion and agendas shifted and financial impacts as questions in the finance world were being asked and some funds shifted.

\subsection{Legitimacy and Reputation}

One of the political impacts of Divestment is damage to the reputation and legitimacy of the fossil fuel industry. Several activist interviewees suggested that they saw this as the real goal of Divestment, for example:

the initial aim is to move the money but also, it's so much more about the social licence, legitimacy and power of those fossil fuel investment funds. (A1, student campaigner)

Divestment aims to reframe the climate change debate to include ethics and politics, in addition to highlighting fossil fuel investments [17]. It seeks:

[to] reframe what we think of as an ethical investment and to include fossil fuels on the list of things that we can no longer invest in from an ethical standpoint and putting them on the same list as things like armaments and tobacco. (A2, former student activist)

A report from the Smith School of Enterprise and the Environment [10] highlights the dangers of 'stigmatisation' of fossil fuel companies, which could scare away suppliers, subcontractors and even potential employees and customers (cultural and political impact). The delegitimisation of the fossil fuel industry is, in other words, "a slower, partly symbolic struggle but it has material consequences in the end" (A6). However, the chair of a research and advocacy group (A5) suggested that while activists have succeeded in embarrassing the finance sector and putting it on the politically defensive, that has not translated into reducing emissions.

In Australia, the coal industry and the government reacted with outrage at a divestment decision a few years ago, for which Jotzo [40] suggests three reasons: First, investments in line with personal values strike a chord with the public; second, companies can receive 'negative visibility'; and third, such decisions highlight the risks in the future of fossil fuel industries. The last of these demonstrates how Divestment has increased uncertainty surrounding fossil fuels investments [10] (potential financial impact). More recently, Divestment in Australia has contested whether the industry is serving public and shareholders' interests, putting the industry on the defensive-it has to defend its usefulness and justify its very existence [15].

These examples show that reputational damage and loss of legitimacy are far more than symbolic struggles and can have serious consequences.

\subsection{Radical Flank Effect}

Activism promoting alternative viewpoints can shift debate through introduction of more extreme opinions, even if they remain on the fringe; this is the radical flank effect. It helps effect institutional 
change by indirectly lending legitimacy to others' positions [35]. Radical positions strengthen moderates' negotiation power, while moderate actions enable radical goals to enter mainstream discourse. For example, environmental activism can enable more moderate, institutionalised NGOs to gain audiences with policymakers [25], as has been observed in the UK in the past [41].

In the case of Divestment, McKibben and 350.org presented an extreme position-that the fossil fuel industry was a public enemy [35]. Even moderate actors agree that "fossil fuel companies have been deliberately misleading and slowing down progress on climate change and continue to be unprepared to change at the pace necessary" (A3). A US-based analysis suggests such views."...expanded the spectrum of the climate change debate and shifted its central focus" ([35], p. 2); the growing attention to radical ideas triggered greater inclusion as more moderate liberal ideas moved into the centre ground. This radical flank effect happened concurrently with the concepts of 'stranded assets' and 'the carbon bubble' entering public discourse, linking Divestment to these mainstream changes [35].

In the finance world, there is evidence of a radical flank effect as "campaigners pushing for an 'ideal' could result in mainstream investors doing what is 'possible'" [30]. The chair of an advocacy group (A5) stated that while Divestment campaigners were idealistic and unrealistic about changing behaviour in the financial world, their actions enabled advocacy with investors.

The radical flank effect contrasts with Ayling's work [15] on the divestment movement seeking legitimacy for itself. However, while the hard-line positions taken by divestment leaders was intentional, I have found no evidence that the radical flank effect was a strategic decision. Nonetheless, the mainstreaming of divestment has opened up political space to more radical ideas, such as questioning whether banks should finance tar sands and fracking projects (A7). Indeed, People and Planet have recently launched a 'Divest Barclays' campaign to stop the bank from "funding any new coal mines, drill any new fracking sites or build any more pipelines" [42].

\subsection{Fiduciary Duty}

One of the weapons of those who oppose divestment action has been the argument of 'fiduciary duty', that is, the obligation of fund managers to act in the best interest of investors and shareholders, often narrowly interpreted as maximising (short term) returns on investment. The argument states that as long as fossil fuels offer the best returns on investment, fund managers cannot legally divest from them, even when that means ignoring the threat of climate change.

This notion has been challenged in recent years from within the finance world, for example, arguing that fiduciary duty should be redefined in the climate change context [17], or that it does not have to mean putting profit before values [11]. Another analysis suggests formally assessing climate change risks could lead to mainstream investors taking 'proportionate action' with a "forward-looking understanding of fiduciary duty" [36] and criticises current practices within the finance sector, including short-termism and the lack of organisational weight behind environmental, social and governance (ESG) issues. A charitable trust officer (A3) highlighted how the discourse has been developing rapidly over the past few years, claiming that it is now seen as a legal obligation to manage climate risks in investments. This is because fiduciary duty includes prudence, especially relevant in long-term investments; fossil fuels pay high dividends but are risky and could therefore be excluded. At UN level, Christiana Figueres urged investors to move away from high carbon assets: "Institutional investors who ignore the [climate change] risk face being increasingly seen as blatantly in breach of their fiduciary duty to their beneficial owners" ([20], p. 1).

In the UK, a Law Commission Review (following the financial crisis) suggested trustees do not have to maximise short-term returns at the expense of the longer term and that they should take into account ESG issues which are financially material to the performance of an investment [43]. Finally, in December 2017 the UK government announced it would introduce new investment regulations allowing pension schemes to mirror ethical concerns of their members, including addressing environmental problems. This could strengthen calls for divestment, as it undercuts the 'fiduciary duty' argument; Divestment has clearly played a part in the public mood shift which allowed this change [44]. 


\subsection{Reinvestment}

The idea of reinvesting in 'climate solutions' is less prominent in Divestment literature and media coverage of the movement. Activist interviewees suggested that reinvestment was happening to some extent but did not have the same momentum as divestment, for several reasons. From a pragmatic perspective, it was seen as strategically disadvantageous to ask for the additional, bigger step of investing funds in particular places. It was also believed there were not enough appropriate funds to invest in and that reinvestment was technically more difficult, for example,

It's relatively straightforward for an investor to exclude fossil fuels. When it comes to solutions, it's harder to identify what good looks like. (A3)

Moreover, activists doubted their own expertise:

It's not down to us, as people who are not expert in financial markets, to identify an alternative for them. (A6)

Nonetheless,

[S]ome UK universities have made reinvestment commitments as a result of divestment. (A7)

Actors in the finance world also point out that "there are not enough good assets to invest in if there were widespread divestment" [45] and that more work is needed on where investments could be redirected [36].

In contrast to the grassroots university activists, more mainstream organisations and funds working on divestment have adopted reinvestment more clearly. For example, investor network DivestInvest [22] proudly announce on their homepage, "Divest from fossil fuels and invest in climate solutions." The shift in investments appears to be entering the mainstream:

A number of major investors, including pension funds and insurance companies, are already starting to shift their investments. For example, over 400 investors with US\$25 trillion in assets have joined the Investor Platform for Climate Actions, committed to increasing low-carbon and climate-resilient investments, including by working with policy-makers to ensure financing at scale. ([46], p. 16)

Moderate and mainstream finance actors have created viable funds and investment streams for reinvestment, using both financial and ethical arguments. While the rising interest in and availability of, 'climate solution' investments cannot be directly attributed to the divestment movement, the change in public discourse catalysed by Divestment appears to be one of the drivers of this shift.

\subsection{Summary}

The indirect impacts of Divestment are summarised in the bottom half of Figure 1. The societal effects (cultural and mobilisation impacts) are not dominated by effects on participants, unlike direct impacts. The political impacts are no longer local and the financial effects are considerably more far-reaching than the direct impacts. While Divestment has by no means single-handedly caused all of these impacts, it played a part in catalysing greater social, political and financial change.

The most prominent impact has been the discourse shift, a clear cultural impact, which in turn has precipitated mobilisation, political and financial impacts, as the notions of divestment entered different public spheres, attracting supporters and causing demands from investors and new conversations among financiers. The challenge to the legitimacy of the fossil fuel industry is more of a political impact as it (potentially) affects power structures and the political agenda. A different political impact is the changing notion of fiduciary duty, culminating in changing government regulations. All of these impact the world of finance, which is engaged in new conversations around shifting investments and stranded assets, as new fossil-free funds are created and regulations shift. The interactions between types of impact are show in Figure 2, and discussed in Section 5. 


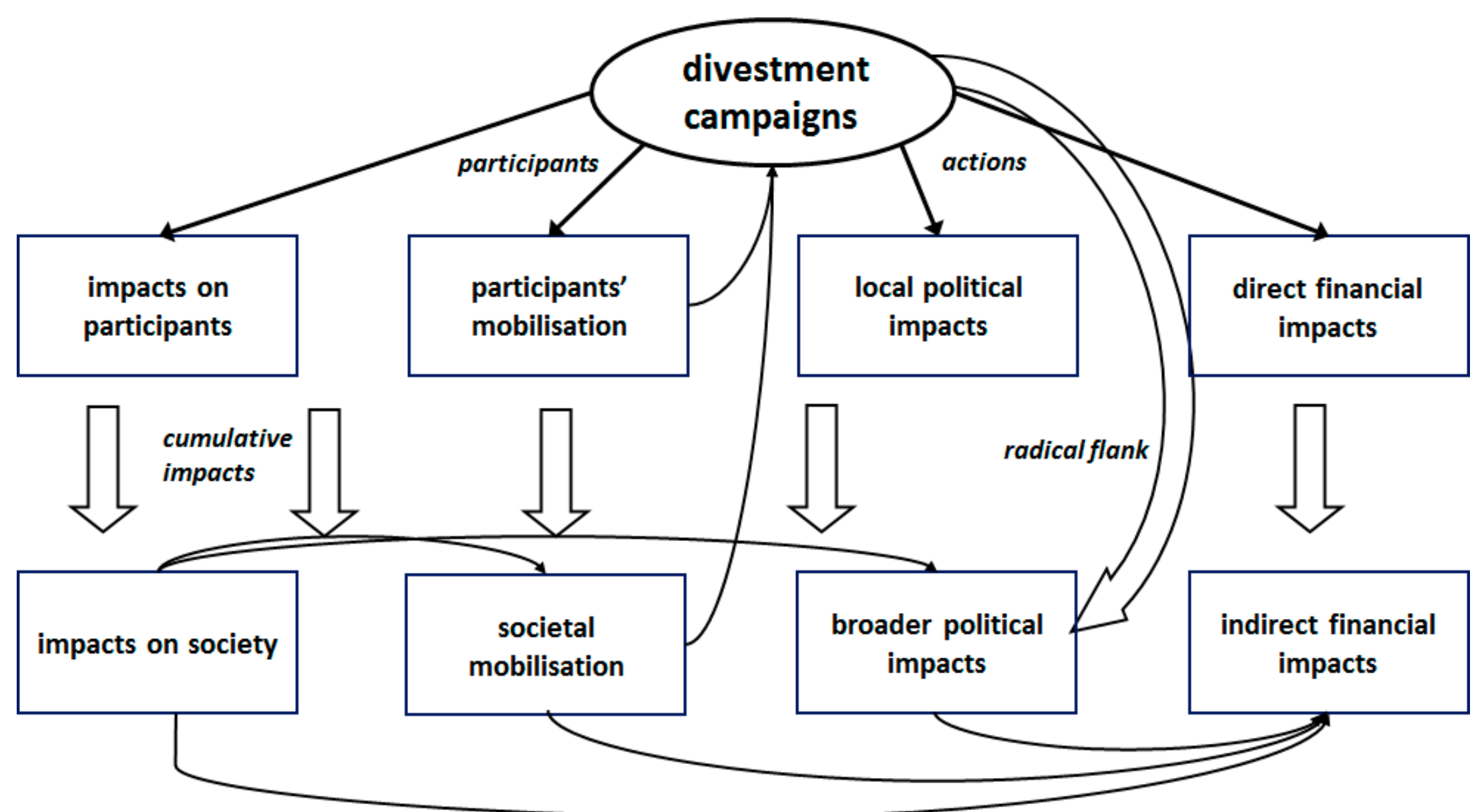

Figure 2. Interactions between impacts and the divestment campaign. Direct impacts cumulatively contribute to the various indirect impacts. In addition, cultural impacts ("impacts on society") affect other indirect impacts and all indirect impacts have a contextual effect which impacts on the finance world. In addition, mobilisation impacts can act as a positive feedback loop by increasing divestment campaigns. Finally, the 'radical flank' effect has indirect political impact, as the more radical demands of Divestment lead to mainstreaming of less radical action on finance and climate. 
An arguably lacking political impact is recognition of a group as legitimate representatives of an issue. The Divestment campaigners are not seen as an authority on fossil fuel finance, nor do they expect to be. This might tie in to the radical flank effect: Divestment has taken a strong stance against fossil fuels, which cannot be taken up by more mainstream actors. Campaigners are therefore not recognised constituents but their radical position has allowed more moderate voices to gain recognition.

\section{Discussion and Conclusions}

This paper has explored the impacts of the social movement for divestment from fossil fuels using literature and interviews with UK activists and financial actors. I propose a hybrid framework using concepts from social movement theory for exploring Divestment impacts, summarised in Figures 1 and 2. I now offer a brief discussion and some conclusions using the three dimensions of the framework: direct and indirect impacts; categories of impact; and impacts on participants versus impacts of campaign actions.

The main limitation of this research is the favourable attitude of most research into Divestment. This limited perspective risks overestimating the movement's impacts and assigning causality to changes that were part of larger processes. I address this by highlighting some explicitly sceptical views throughout the paper; by focusing on qualitative, not quantitative change; and by analysing Divestment in context as an environmental movement in the discussion below.

\subsection{Direct and Indirect Impacts}

Much of the criticism of Divestment is that it has been ineffective, having little impact on fossil fuel finance. Indeed, divestment has so far had little effect on publicly traded companies, let alone government owned companies. In other words, "the obvious metrics by which the movement could be judged point to failure" ([35], p. 2). However, collapsing fossil fuel finance was never the real goal of the movement. Rather, Divestment's main focus is normative-raising awareness over the urgency of transitioning to a low-carbon economy [6]. It has changed public discourse in the UK and elsewhere, giving the media a new way to cover the climate change story and making it harder for politicians to show wilful blindness towards the issue [30]. In doing so, Divestment disrupted a stalemate in climate change discourse [35], changing discussions in the finance world and affecting some investors' and shareholders' attitudes towards fossil fuel companies. Finally, Divestment has stigmatised the fossil fuel industry [10] and challenged its legitimacy, putting it on the defensive [15]. Overall, this paper strongly supports other research [10] in concluding that the indirect impacts of Divestment significantly outweigh its direct impacts and further suggests that Divestment's impacts are best measured through its indirect effects on culture, politics and finance.

The indirect impacts are to some extent the influence of cumulative direct impacts (see Figure 2), whereby the growing visibility and volume of Divestment shifts the discourse and causes more actors to divest. However, the radical flank effect highlights another path, whereby actors who might disagree with the radical message of Divestment promote more moderate modes of engagement and action; these are in turn legitimised through their contrast with the 'radical flank.' A second conclusion is therefore that this dimension offers insight into different paths to impact.

\subsection{Cultural, Mobilisation, Political and Financial Impacts}

I find Staggenborg's [26] categories of cultural, mobilisation and political impacts useful as they have different roles. Cultural effects, amplified through mobilisation, can catalyse further impacts. Mobilisation impacts are important in their positive feedback effect, where Divestment activists and more broadly, active shareholders and other actors, increase the overall action and volume of Divestment, thereby increasing its impact. Political impacts might be slower but can have significant consequences for the financial world, as seen in the fiduciary duty example. More broadly, divestment is playing a part in a broader political shift which is "weakening the political and economic stronghold 
of the fossil fuel industry" [13]. Bernstein [29] argues that activists' strategies are affected by ideology but also by "how they understand the relationship among mobilization, political and cultural effects" (p. 359). I suggest that while there was some ideological naivete among activists, on the whole Divestment portrayed a conscious strategic choice for cultural effects around changing norms of investments in fossil fuels. In doing so, Divestment has successfully raised questions of how to engage with decision making on energy investments.

For this case study, I added financial impacts. Effects in the financial world can be seen in changing ideas of 'fiduciary duty', changing regulations and creation of fossil-free funds. Divestment has clearly played a part in this shift, even if its role is hard to quantify. Furthermore, I suggest that Divestment carries the threat of financial impact, even if its impact so far is small. This potential impact is through stigmatisation of the industry and through increasing uncertainty around fossil fuels with the stranded assets discourse and can be seen in shareholder action and the defensive actions of the fossil fuel industries. For example, active investors can make a difference in the financial world, because "Ensuring that pension funds and other asset stewards recognise that they are being actively watched—and could be at risk of legal challenge on the issue-is, to be realistic, part of the change process" [36].

Finally, this research makes a contribution in demonstrating how these impact categories affect each other (bottom of Figure 2). In the Divestment example, cultural effects in the form of discourse change play a significant part in mobilisation, political and financial effects; while all categories can affect financial impacts.

\subsection{Impacts on Participants and Impacts of Action}

The third, and least developed, dimension of the framework is the distinction between impacts on Divestment participants and impacts of the campaigns themselves. I suggest this is an important dimension too, as participants' experiences can shape the movement, as can be seen in the above discussion about strategy, naiveté and ideology. Impacts on participants were evident both in terms of personal empowerment, taking people from being bystanders to being engaged participants and activists, and in terms of reviving the (student) environmental movement. Divestment provides a model in which different actors can participate and where the sum of local actions has a global impact. In this respect, the networked nature of the movement has had another important success-overcoming the well-known difficulty of scaling up resistance (e.g., [47]). It thereby offers a novel form of non-state governance that can play a significant role in social steering and catalysing effective climate change mitigation [6].

Personal experiences shape the dynamics and longevity of social movements. In the UK, there have been waves of environmental protests over recent decades (e.g., [48]). The reasons environmental activism rises and falls are not fully understood but burnout and exhaustion are thought to have played a part in the decline in UK activism in the early 2000s [48,49]. Divestment is for the most part far less confrontational than the road protests of the 1990s, so we can expect personal experiences to be different. Future research could further unpack how different types of activism impact on participants and in turn how that affects the success and longevity of social movements, specifically environmental protest movements.

A final recommendation for future research is the role of the media. Media reporting can be indicative of political impact but not necessarily of protest activity [49], as mainstream media both records and affects visibility of protest but does not accurately reflect its scale or frequency [50]. The fairly positive media experience of Divestment contrasts with the complex, and often suspicious, relationship with mainstream media that other environmental activism has had (e.g., [41]). The media's role in the rise of Divestments is therefore of particular interest.

Funding: This work was supported by the Research Councils United Kingdom (RCUK) Energy Programme [grant $\mathrm{EP} / \mathrm{K} 011790 / 1$, "Centre on Innovation and Energy Demand" (CIED)]. Any opinions, findings and conclusions or recommendations expressed in this material are those of the author and do not necessarily reflect the views of RCUK Energy Programme. 
Acknowledgments: The author would like to thank Tim Foxon for useful feedback on this work and Harriet Dunn for sharing her dissertation, which included interviews with student divestment activists.

Conflicts of Interest: The authors declare no conflicts of interest.

\section{References}

1. International Energy Agency (IEA). World Energy Outlook 2021; International Energy Agency: Vienna, Austria, 2012.

2. Leaton, J. Unburnable Carbon-Are the World's Financial Markets Carrying a Carbon Bubble? Carbon Tracker: London, UK, 2011.

3. McGlade, C.; Ekins, P. The geographical distribution of fossil fuels unused when limiting global warming to $2{ }^{\circ}$ C. Nature 2015, 517, 187-190. [CrossRef] [PubMed]

4. $\quad$ Erickson, P.; Lazarus, M.; Tempest, K. Carbon Lock-In from Fossil Fuel Supply Infrastructure; Stockholm Environment Institute: Seattle, WA, USA, 2015.

5. Van Asselt, H. Governing the transition away from fossil fuels: The role of international institutions. Stock. Environ. Inst. Work. Pap. 2014, 7. [CrossRef]

6. Ayling, J.; Gunningham, N. Non-state governance and climate policy: The fossil fuel divestment movement. Clim. Policy 2017, 17, 131-149. [CrossRef]

7. Alexander, S.; Nicholson, K.; Wiseman, J. Fossil Free: The Development and Significance of the Fossil Fuel Divestment Movement; MSSI Issues Paper; Melbourne Sustainable Society Institute, The University of Melbourne: Melbourne, Australia, 2014; pp. 1-16.

8. 350.org. Available online: https://350.org/ (accessed on 13 October 2017).

9. Tollefson, J. Reality check for fossil-fuel divestment. Nature 2015, 521, 16-17. [CrossRef] [PubMed]

10. Ansar, A.; Caldecott, B.; Tilbury, J. Stranded Assets and the Fossil Fuel Divestment Campaign: What Does Divestment Mean for the Valuation of Fossil Fuel Assets; Smith School of Enterprise and the Environment, University of Oxford: Oxford, UK, 2013.

11. Dorsey, E.; Mott, R.N. Philanthropy Rises to the Fossil Divest-Invest Challenge. Available online: https:/ / www.huffingtonpost.com/ellen-dorsey / philanthropy-rises-to-the_b_4690774.html (accessed on 18 July 2018).

12. McKibben, B. Global Warming's Terrifying New Math. Available online: https:/ /www.rollingstone.com/ politics / politics-news / global-warmings-terrifying-new-math-188550 / (accessed on 18 July 2018).

13. Grady-Benson, J.; Sarathy, B. Fossil fuel divestment in US higher education: Student-led organising for climate justice. Local Environ. 2016, 21, 661-681. [CrossRef]

14. Fossil Free Fossil Free: Divestment. Available online: http:/ /gofossilfree.org/frequently-asked-questions/ (accessed on 16 April 2018).

15. Ayling, J. A Contest for Legitimacy: The Divestment Movement and the Fossil Fuel Industry. Law Policy 2017, 39, 349-371. [CrossRef]

16. Devinney, T. The Guardian's Fossil Fuel Divestment Campaign Could Do More Harm Than Good. Available online: https: / theconversation.com/the-guardians-fossil-fuel-divestment-campaign-could-domore-harm-than-good-39000 (accessed on 14 November 2017).

17. Healy, N.; Debski, J. Fossil fuel divestment: Implications for the future of sustainability discourse and action within higher education. Local Environ. 2017, 22, 699-724. [CrossRef]

18. Ressler, L.; Schellentrager, M. A Complete Guide to Reinvestment. Available online: https:/ /s3.amazonaws. com/s3.350.org/images/Reivestment_Guide.pdf (accessed on 22 July 2016).

19. Power Shift Reinvestment in Climate Solutions. Available online: https://powershift.org/campaigns/ divest/alternatives (accessed on 18 April 2018).

20. United Nations Common Coding System (UNCCS). Safeguarding Future Retirement Funds-Time for Investors to Move out of High-Carbon Assets Says UN's Top Climate Official; United Nations Common Coding System (UNCCS): New York, NY, USA, 2014.

21. Weber, O.; Hunt, C. Want a Richer Pension? Divest of Fossil Fuels. Available online: https://theconversation. com/want-a-richer-pension-divest-of-fossil-fuels-93850 (accessed on 17 April 2018).

22. DivestInvest.org. Available online: https:/ / www.divestinvest.org/ (accessed on 13 October 2017). 
23. Dunn, H. Student Activism and the Climate Movement: An Exploration of Motivations, Successes and Challenges within the Fossil Fuel Divestment Campaign; University of Sussex: Brighton, UK, 2016.

24. Snow, D.A.; Soule, S.A.; Kriesi, H. Mapping the terrain. In The Blackwell Companion to Social Movements; Snow, D.A., Soule, S.A., Kriesi, H., Eds.; Blackwell: Oxford, UK, 2004; pp. 3-16, ISBN 9780631226697.

25. Rootes, C.; Nulman, E. The Impacts of Environmental Movements. In The Oxford Handbook of Social Movements; della Porta, D., Diani, M., Eds.; Oxford University Press: Oxford, UK, 2015; pp. 729-742.

26. Staggenborg, S. Can Feminist Organizations Be Effective? In Feminist Organizations: Harvest of the New Women's Movement; Ferree, M.M., Martin, P.Y., Eds.; Temple University Press: Philadelphia, PA, USA, 1995; pp. 339-355, ISBN 9781439901564.

27. Giugni, M.G. Was It Worth the Effort? The Outcomes and Consequences of Social Movements. Annu. Rev. Sociol. 1998, 24, 371-393. [CrossRef]

28. Marchetti, R. The Conditions for Civil Society Participation in International Decision Making. In The Oxford Handbook of Social Movements; della Porta, D., Diani, M., Eds.; Oxford University Press: Oxford, UK, 2015; pp. 753-766.

29. Bernstein, M. Nothing Ventured, Nothing Gained? Conceptualizing Social Movement "Success" in the Lesbian and Gay Movement. Sociol. Perspect. 2003, 46, 353-379. [CrossRef]

30. Thamotheram, R. The Fossil Fuel Divestment Debate: Is There a Consensus Way Forward? Available online: https:/ / www.responsible-investor.com/home/article/rt_div/ (accessed on 14 November 2017).

31. Solomon, C. We felt liberated. In Springtime: The New Student Rebellions; Solomon, C., Palmieri, T., Eds.; Verso: London, UK, 2011; pp. 11-16, ISBN 9781844678242.

32. Piketty, T.; Jackson, T. Responsible Investors Must Divest from Fossils Fuels Now. The Guardian, 14 November 2015.

33. Harrell, C.; Bosshard, P. Insuring Coal no More: An Insurance Scorecard on Coal and Climate Change. Available online: https:/ / unfriendcoal.com/scorecard/ (accessed on 16 November 2017).

34. Kemp, L. The Fossil Fuel Divestment Game Is Getting Bigger, Thanks to the Smaller Players. Available online: https:/ / theconversation.com/the-fossil-fuel-divestment-game-is-getting-bigger-thanksto-the-smaller-players-65109 (accessed on 19 December 2017).

35. Schifeling, T.; Hoffman, A.J. Bill McKibben's Influence on U.S. Climate Change Discourse: Shifting Field-Level Debates through Radical Flank Effects. Organ. Environ. 2017, 1-21. [CrossRef]

36. Thamotheram, R. Part 3: Fossil Fuel Divestment: Is There a "Common Ground" Strategy? Available online: https:/ / www.responsible-investor.com/home/article/rt_3/ (accessed on 14 November 2017).

37. Goldenberg, S. Heirs to Rockefeller Oil Fortune Divest from Fossil Fuels over Climate Change. Available online: https://www.theguardian.com/environment/2014/sep/22/rockefeller-heirs-divestfossil-fuels-climate-change (accessed on 18 July 2018).

38. Leggett, J. Exxon, Dismissing Risk of Carbon Stranded Assets, Accused of Naivety. Available online: http: / / www.jeremyleggett.net/2014/04/exxon-dismisses-risk-of-stranded-assets-from-carbon/ (accessed on 16 November 2017).

39. Linnenluecke, M.K.; Meath, C.; Rekker, S.; Sidhu, B.K.; Smith, T. Divestment from fossil fuel companies: Confluence between policy and strategic viewpoints. Aust. J. Manag. 2015, 40, 478-487. [CrossRef]

40. Jotzo, F. Outrage at ANU Divestment Shows the Power of Its Idea. Available online: https://theconversation. com/outrage-at-anu-divestment-shows-the-power-of-its-idea-32736 (accessed on 13 October 2017).

41. Bergman, N. Climate Camp and public discourse of climate change in the UK. Carbon Manag. 2014, 5, 339-348. [CrossRef]

42. People \& Planet People \& Planet. Available online: https:/ / peopleandplanet.org/ (accessed on 12 April 2018).

43. ShareAction. The Law Commission's Review of Fiduciary Duties: What It Means for Pension Funds; ShareAction: London, UK, 2014.

44. Collinson, P. Boost for Fossil Fuel Divestment as UK Eases Pension Rules. Available online: https: / / www.theguardian.com/environment/2017/dec/18/boost-for-fossil-fuel-divestment-asuk-eases-pension-rules (accessed on 18 December 2017).

45. Thamotheram, R. Part 2: What Impact Could Divestment Have on Share Price and the Energy Sector? Available online: https://www.responsible-investor.com/home/article/rt_ff/P0/ (accessed on 14 November 2017). 
46. New Climate Economy. The Sustainable Infrastructure Imperative: Financing for Better Growth and Development; The Global Commission on the Economy and Climate: London, UK, 2016.

47. Featherstone, D. Towards the relational construction of militant particularisms: Or why the geographies of past struggles matter for resistance to neoliberal globalisation. Antipode 2005, 37, 250-271. [CrossRef]

48. Plows, A. Blackwood roads protest 2004: An emerging (re)cycle of UK eco-action? Environ. Polit. 2006, 15, 462-472. [CrossRef]

49. Doherty, B.; Plows, A.; Wall, D. Environmental direct action in Manchester, Oxford and North Wales: A protest event analysis. Environ. Polit. 2007, 16, 805-825. [CrossRef]

50. Rootes, C. The Transformation of Environmental Activism: An Introduction. In Environmental Protest in Western Europe; Rootes, C., Ed.; Oxford University Press: Oxford, UK, 2004; ISBN 9780191601064.

2018 by the author. Licensee MDPI, Basel, Switzerland. This article is an open access article distributed under the terms and conditions of the Creative Commons Attribution (CC BY) license (http:// creativecommons.org/licenses/by/4.0/). 